\title{
Alberto Bernard. « Il Filosofo, lo Šāh e i Magi: l'ambasceria di Eustazio di Cappadocia a Šābuhr II (Eunapio, Vite dei filosofi e sofisti, VI, 5, 1-10)»
}

\section{Olivia Ramble}

\section{(2) OpenEdition}

Journals

Édition électronique

URL : http://journals.openedition.org/abstractairanica/50816

DOI : 10.4000/abstractairanica. 50816

ISBN : 1961-960X

ISSN : 1961-960X

Éditeur :

CNRS (UMR 7528 Mondes iraniens et indiens), Éditions de l'IFRI

\section{Référence électronique}

Olivia Ramble, « Alberto Bernard. « Il Filosofo, lo Šāh e i Magi: I'ambasceria di Eustazio di Cappadocia a

Šābuhr II (Eunapio, Vite dei filosofi e sofisti, VI, 5, 1-10) » », Abstracta Iranica [En ligne], Volume 40-41 |

2019, document 7, mis en ligne le 30 décembre 2019, consulté le 20 avril 2021. URL : http://

journals.openedition.org/abstractairanica/50816; DOI : https://doi.org/10.4000/abstractairanica 50816

Ce document a été généré automatiquement le 20 avril 2021.

Tous droits réservés 


\title{
Alberto Bernard. « Il Filosofo, lo Šāh e i Magi: l'ambasceria di Eustazio di Cappadocia a Šābuhr II (Eunapio, Vite dei filosofi e sofisti, VI, 5, 1-10)»
}

\author{
Olivia Ramble
}

\section{RÉFÉRENCE}

Alberto Bernard. « Il Filosofo, lo Šāh e i Magi: l'ambasceria di Eustazio di Cappadocia a Šābuhr II (Eunapio, Vite dei filosofi e sofisti, VI, 5, 1-10) », Bizantinistica. Rivista di Studi Bizantini e Slavi 19, 2018, p. 85-117

1 Un passage des Vies d'Eunape concerne une ambassade envoyée auprès de Šābuhr II, guidée par le néoplatonicien Eustace. Cet article en analyse la construction littéraire (rencontre d'un holy man païen et d'un roi perse, tentative de conversion philosophique, imagerie persane, etc.) avec en arrière-plan la diplomatie romano-perse du IVe siècle. L'A. s'attarde ensuite sur un détail jusqu'à présent négligé : la mission aurait échoué, selon Eunape, à cause de l'ingérence de certains « mages » (gr. màgoi). Il montre que le mot màgos y est employé dans le sens technique de «prêtre (zoroastrien) " (m.p. mow, mowbed) et non celui de "magicien », et que la présence des mages à la cour ne s'explique qu'en tenant compte de l'importance croissante du clergé zoroastrien dans l'empire sassanide. L'A. relève que, sur ce phénomène, l'historiographie "classicisante " demeure silencieuse, contrairement aux nouveaux genres (historiographie ecclésiastique; vies et actes des martyrs etc.) et littératures (syriaque, manichéenne, arménienne, etc.) nés dans l'empire ou dans sa périphérie. C'est ainsi dans la "mise en série » avec ces sources que le récit d'Eunape devient un 
témoignage singulier et précoce d'une réalité historique (le poids social des mages sassanides) et d'un topos littéraire (leurs machinations néfastes à la cour).

\section{AUTEURS}

\section{OLIVIA RAMBLE}

Doctorante EPHE, Mondes iranien et indien, Paris 